\title{
EVALUATION OF ANTAGONISTIC PLANT MATERIALS TO CONTROL SOUTHERN ROOT KNOT NEMATODE (Meloidogyne incognita) IN TOMATO
}

\author{
Arun Kafle
}

\begin{abstract}
Marigold ((Tagetes patula), crotalaria (Crotalaria juncia), rapeseed plant (Brassica rapa) and oat(Avena sativa) as antagonistic plant and tomato (Lycopersicon esculentum), CL1104 variety as control, were evaluated to determine the effect on southern root knot nematode population in pot experiment at Tsukuba, Japan in year 2010. Completely Randomized Design (CRD) with three replications was used. Initial juvenile population was $30.0 \pm 2.8$ per $20 \mathrm{~g}$ soil. The juvenile nematode population was counted 63 days after transplanting and biomass of plants was incorporated in soil. Population was again counted 11 days and 13 day after biomass incorporation. At final count of Juvenile nematode population, it was found highest in tomato $(66.6 / 20 \mathrm{~g}$ soil). Highest control was achieved in marigold (2.3 juvenile/20g soil) followed by crotalaria (3.0 juvenile/20g soil). Marigold and crotalaria followed by oat in rotation with tomato were observed as best antagonist plants to control Southern root knot nematode.
\end{abstract}

KEY WORDS: Antagonistic plants, tomato, Nematode infested soil, Southern root knot nematode, juvenile, Nepal.

\section{INTRODUCTION}

Root knot nematode (Meloidogyne spp.) is distributed worldwide in areas with warm or hot climate and short or mid-winter and in greenhouse. They attack more than 2000 species of plants including almost all cultivated crops and on an average reduce the crop production by $5 \%$ in the world (Agrios, 2005a). Among the cultivated vegetables, tomato, eggplant, okra, peppers, gourds and melons are highly susceptible to root knot nematode. In tomato and eggplant $20-40 \%$ loss is caused by root knot nematode (Bridge and Starr, 2007).

Tomato is major vegetable consumed in Nepal which occupies fifth position in terms of area coverage after cauliflower, cabbage, radish and onion. Tomato alone covers 117,043 ha land with the average productivity of $17.1 \mathrm{mt} / \mathrm{ha}$ (VDD, 2011). Cultivation of tomato using plastic house is one of the profitable enterprises of farmers of Nepal. Several small scales as well as commercial farmer are engaged in tomato cultivation inside plastic house in most of the midhills of Nepal.

The area of tomato under plastic house is increasing year after year. Due to the continuous cropping of tomato problem of various diseases and insects are becoming severe, among them, root knot nematode (Meloidogyne spp.) is the major one identified through farmers field survey.

${ }^{1}$ Vegetable Development Officer, VDD,Khumaltar, e-mail : a_kafle@yahoo.com 
The incidence of root knot nematode was first recorded in Nepal by Amatya and Shrestha in the year 1969 on tomato, eggplant, okra and chilli, among several species Meloidogyne incognita is the dominant species responsible for excessive loss in tomato (Bhardwaj and Hogger, 1984). Root knot nematode is also responsible for increasing severity of other disease and pest. Fusarium wilt of several plant increases in incidence and severity when the plants are affected by root knot nematode. Similarly Verticillium wilt, Pythium damping off, Rhizoctonia and Phytopthora root rot are increased due to root knot nematode infection (Agrios, 2005b).

In Nepal nematode resistant tomato varieties are unavailable. The problem is seen from the nursery stage and huge damage occurred during flowering and fruiting period. Due to limited land available for cultivation and investment of huge amount of money for the construction of fixed rain shelter type of plastic house (more than NRs 25,000 form75 $\mathrm{m}^{2}$ area) most of the farmers are not able to shift land every year.

Several plants are reported as antagonistic to the nematodes. Lespedeza (Lespedeza spp.), common vetch(Vicia sativa), velvet bean(Mucuna pruriens), lupine(Lupinus perennis), castor(Ricinus communis), rapeseed plant(Brassica rapa), giselba mustard(Brassica hirta), andmarigold (Tagetes patula) are the major green manuring crop having property to control root knot nematode (Crow et al, 1995). The different plant antagonists like rape seed (Brassica campestris, $B$. napus) and Sudan grass (Sorghum vulgare var sudanense) contains glucosinolate and cyanogenic glycoside compounds having pesticidal property on nematode (Santo et al., 1991). Marigold can suppress 14 genera of plant-parasitic nematodes including root-knot nematodes (Meloidogyne spp.) (Suatmadji 1969). Crotalaria is a poor host of many plant parasitic nematodes including Meloidogyne Spp. (Wang et.al. 2002a). Oat (Avena sativa) is known for resistance from pest to disease and grown to break life cycles of soil borne pest and diseases. Oat possesses secondary metabolites that impart resistance to nematode (Osbourn, 2003). Nematode suppressive crops prevent the buildup of damaging levels of nematodes naturally without nematicides (Gazaway, 1998). Use of low cost technology to suppress nematode population for the better yield of tomato is needed in Nepalese condition. We have diverse range of plants that are reported as nematode suppressive. Thus use of such plants for controlling root knot nematode in tomato without costly nematicides may one of the possible options for small scale tomato growers. The main objective of this experiment is to evaluate effect of selected antagonistic plants to control southern root knot nematode.

\section{METHODOLOGY}

\section{EXPERIMENTAL SETUP}

This experiment was carried out in pots $(35 \mathrm{~cm}$ diameter).Plant pathology glasshouse of TBIC was used from May to October 2010. In each treatment 4 plastic pots were used. Completely randomized design (CRD) was used. Following 
five treatments with three replications were used (Table 1). Altogether 60 pots containing nematode infested soil were used for the experiment.

Table 1. Treatment details

\begin{tabular}{llll}
\hline Treatments & Scientific name & Varieties & Source \\
\hline Rapeseed plant & Brassica rapa & Kyoto fusimi & Takii seed \\
Crotalaria & Crotalaria juncea & Nemaking & Yukigirusi \\
Marigold & Tagetes Patula & Dierin & Takii seed \\
Oat & Avena sativa & Tachibuki & Takii seed \\
Tomato (CL1104) & Lycopersicon esculentum & CL 1104 & TBIC \\
\hline
\end{tabular}

\section{MATERIALS}

Following materials were used during experimental works

- Garden balsam as susceptible host

- Nematode infested soil

- $\quad$ Nematode suppressive plants and tomato plant as treatment

- $\quad$ Pot(35 cm diameter) filled with 6 liter field soil

- Media soil for rising seedlings

- $\quad$ Plastic pot (6 inch diameter) for growing balsam as host

- Plastic pot( $6 \mathrm{~cm}$ diameter) for raising seedling of treatment and tomato plants

\section{Preparation of nematode infested soil}

Garden balsam was seeded as the host plant for nematode. About $30 \mathrm{~kg}$ nematode infested soil was obtained from National Agricultural Research Center (research team for detection of plant pathogens and nematodes) located in Tsukuba. Initial nematode population of infested soil obtained from the research station was counted (5 juvenile per $100 \mathrm{~g}$ soil). 60 pots of 6 inch diameter were filled with $500 \mathrm{~g}$ infested soil in each pot.30 days old one balsam seedlings in each pot were transplanted. Gall formation in balsam root was observed within 25 days after transplanting. Infested soil with galled balsam roots was collected; mixed, heaped and nematode population was again counted. Following the similar procedure, large quantity of nematode infested soil was prepared to carry out experiment. Two liter infested soil per pot was used for carrying out experiment.

\section{Cultivation of treatment plants}

Seed of antagonist plants and tomato were seeded in cell tray made form plastic for raising seedling and transferred into $6 \mathrm{~cm}$ diameter pot after 15 days. In each experimental pot five seedlings of marigold (35 days old), oat ( 25 days old), rapeseed plant ( 25 days old) and crotalaria ( 25 days old) were transplanted. One tomato plant ( 25 days old CL 1104 variety) was planted in control pot. Plants were cultivated form July 24 to October 9 .Watering and weeding according to need was done. 


\section{Sampling}

Soil sampling was carried out from the pot within $15 \mathrm{~cm}$ depth because distribution is greater in or around the root of susceptible plants (Agrios, $2005 \mathrm{c}$ ). Soil was mixed properly, sieved and $20 \pm 0.08 \mathrm{~g}$ soil was used for counting nematode population from each treatment. One sample from each treatment pot (15 soil sample from the three replications) was taken for counting nematode in each measurement. Altogether three times sampling on three different dates were done.

\section{Counting nematode population}

Baernmann funnel method was used for the isolation of juvenile nematode from soil which is common method (Bridge and Starr, 2007 b). After 24 hours juvenile nematode population was counted using $1 \mathrm{ml}$ water collected through Baernmann funnel. Compound microscope was used for observation. Nematode population before setting treatment was counted. First counting was done 63 days after transplanting (DAT) then plant biomass of these pots were incorporated and nematode population was counted after 11 days from same pot. Final counting was done 76 days after transplanting.

\section{DATA ANALYSIS}

The obtained data were tabulated and statistically analyzed. ANOVA program developed by Dr.Yamada, Mitate (Technical advisor, JICA, Tsukuba) was used. Turkey's honestly significant difference (HSD, reference?) test was used for comparing means .Turkey's HSD test determines which of three or more sample means are significantly different after ANOVA has indicated that all population means are equal and is application under the condition of equal sample size and assumption of ANOVA fulfilled.(LeBlanc,2004).

\section{RESULTS AND DISCUSSIONS}

\section{NEMATODE POPULATION BEFORE SETTING TREATMENT}

Nematode populations of infested soil were counted before planting antagonists and tomato plant. $30 \pm 2.8$ Juvenile root knot nematodes in $20 \mathrm{~g}$ soil were observed before setting treatment.

\section{NEMATODE POPULATION IN DIFFERENT TIME PERIODS}

The effect of days and treatment on nematode population is given in Table 2 . Population of juveniles counted at three different date $(63,74$ and 76 DAT) were observed as non -significant. The treatment effect for controlling nematode population was significant. While comparing the nematode population, soil with marigold treatment showed best control ( 2.4 juveniles $/ 20 \mathrm{~g}$ soil) followed by crotalaria and oat (4.2 and 6.7 juvenile per $20 \mathrm{~g}$ soil). Rapeseed plant was almost 
ineffective for controlling nematode. The population of juvenile was observed highest in nematode susceptible tomato (63.3 juvenile/ $20 \mathrm{~g}$ soil).

Table 2. Days and treatment wise nematode population

\begin{tabular}{lll}
\hline Days of count & Treatments & $\begin{array}{l}\text { Juvenile nematode population(20 g } \\
\text { soil) }\end{array}$ \\
\hline 63 days & & $20.6 \mathrm{a}$ \\
$74^{*}$ days & & $19.7 \mathrm{a}$ \\
$76^{* *}$ days & $19.3 \mathrm{a}$ \\
& Tomato (CL 1104) & $63.3 \mathrm{a}$ \\
& Rapeseed plant & $22.7 \mathrm{~b}$ \\
& Marigold & $2.4 \mathrm{~d}$ \\
& Crotalaria & $4.2 \mathrm{~cd}$ \\
& Oat & $6.7 \mathrm{c}$ \\
\hline HSD for days A (0.05) & & 4.1 \\
HSD for treatments B (0.05) & 6.2 \\
\hline
\end{tabular}

* 11 days of biomass incorporation in soil ( 63 days of growing +11 days

** 13 days of biomass incorporation in soil ( 63 days of growing +13 days)

The interaction effect of days and treatment on nematode population counted at different date is presented in Table 3. Juvenile nematodes were counted at three different dates to compare the effectiveness of antagonist plants over time period. The population of juvenile nematode in nematode susceptible tomato variety (CL1104) was almost became more than double (66.6 juvenile) within 76 days. Tomato (CL1104) is one of the suitable hosts for Southern root knot nematode contributing favorable environment for increasing population. In this experiment, almost all the rapeseed plants died within 35 days after transplanting due to excess heat in greenhouse (more than 400c for about 20 days).So the effect of rapeseed plant as antagonist was found non-significant. The final nematode population in rapeseed plant was 20 juveniles per $20 \mathrm{~g}$ soil.

In first count (63 DAT) best control was observed in case of marigold (2.6 juvenile/20 g of soil) followed by crotalaria (6.6 juvenile / $20 \mathrm{~g}$ soil). Plant biomass was incorporated in soil for about 11 days to check effect of biomass incorporation for controlling nematode population. No significant effect of biomass incorporation on reducing juvenile population was observed in all treatment. In last count (76 DAT) best control was observed in marigold (2.3 juvenile/20 g soil) followed by crotalaria ( 3.0 juvenile/20g soil) and oat (4.6 juvenile/20 g soil).

The best control of nematode was obtained through growing marigold as cover crop. Wang et al. (2007) mentioned allelopathy phenomenon of marigold responsible for reducing nematode population. He explained a- therthienyl as most toxic compound with nematicidal, insecticidal, fungicidal, antiviral and cytotoxic activities. He found nematicidal activity in root of growing marigold 
plant but not in leaf and root extract. In this experiment, biomass incorporation did not showsignificant effect which is also supported by the above statement of Wang et al.

Table 3. Interaction effect of days and treatment on nematode population

\begin{tabular}{lllll}
\hline Treatments & $\begin{array}{l}\text { Nematode } \\
\text { population in } \\
\text { 20 g soil } \\
\text { (initial) }\end{array}$ & $\begin{array}{l}\text { Nematode } \\
\text { population in } \\
20 \text { g soil ( 63 } \\
\text { days) }\end{array}$ & $\begin{array}{l}\text { Nematode } \\
\text { population in } \\
20 \text { g soil ( } 74\end{array}$ & $\begin{array}{l}\text { Nematode } \\
\text { population in } \\
\text { 20 g soil ( }\end{array}$ \\
& & $60.3 \mathrm{a}$ & $63.0 \mathrm{a}$ & $76^{* * *}$ days) \\
\hline Tomato (CL 1104) & & $24.3 \mathrm{~b}$ & $24.0 \mathrm{~b}$ & $66.6 \mathrm{a}$ \\
Rapeseed plant & $30 \pm 2.8 \mathrm{~b}^{*}$ & $2.6 \mathrm{~d}$ & $2.3 \mathrm{~d}$ & $2.3 \mathrm{~d}$ \\
Marigold & & $6.6 \mathrm{~cd}$ & $3.0 \mathrm{~d}$ & $3.0 \mathrm{~d}$ \\
Crotalaria & & $9.3 \mathrm{~cd}$ & $6.3 \mathrm{~cd}$ & $4.6 \mathrm{~d}$ \\
Oat & & 14.4 & 14.4 & 14.4 \\
\hline HSD A X B (0.05) & & & \\
\hline
\end{tabular}

*11 days of biomass incorporation in soil (63 days of growing+11 days)

**Average nematode population counted three times from each replication randomly before setting treatment Mean represented by same letter are non- significant at $5 \%$ level of significance

Crotalaria was observed as good antagonistnext to marigold Because in comparison to control, 90 percent reduction in population of southern root knot nematode population was observed at $5 \%$ level of significance. The suppression effect of nematode by crotalaria depends upon the method of use (by which means? explain).Most crotalaria pre-plant cover crop followed by incorporation of biomass into soil is reported as effective for controlling root knot nematode by several researchers. So in this experiment crotalaria was used as pre plant cover crop. According to Sharma and Scholari (1984), Crotalaria can suppress Meloidogyne spp. better than nematicide when planted as pre-plant cover crop. As reported by several authors crotalaria acts as non-host, release antagonistic chemical, provides niche for antagonistic flora and fauna, and traps nematode (Wang et.al, 2002b). Similar effect was reported by Wang et.al. (2002c) when incorporated in soil but in this experiment the effect of biomass incorporation was not observed. One of the possible causes of this may be shorter period of incorporation into soil.

Oat has multiple benefits. It is commonly grown as green manure winter crop in many countries. ) Oat also showed good result for controlling southern root knot nematode as compared to rapeseed but it is not much effective as compared to marigold and crotalaria. According to Valenzuela and Smith (2002) oat helps to control weed in field, add biomass in soil, which has allelopathic properties for nematode and plant itself, is resistance from root knot nematode.

Population density and duration of growing antagonist plant in field should be sufficient to control the Southern root knot nematode population. For effective control, root of the antagonist plant should cover upper $15 \mathrm{~cm}$ layer of infested soil during cultivation period. Marigold followed by crotalaria and oat were confirmed as good antagonist plants for reducing juvenile southern root knot nematode population in soil. 
The juvenile root knot nematode population counted at two different time periods(63 DAT and 76 DAT) without biomass incorporation were compared with the population of juvenile before setting treatment (Figure 1). The rate of multiplication of nematode in case of root knot susceptible tomato (CL1104) was very fast. Within 63 days 60.3 juvenile per $20 \mathrm{~g}$ soil were observed and reached up to 66.6 juvenile after 76 days from initial level (30 juvenile). These levels(63 days and 76 days) were significantly increased from initial population. In oat it was reduced to 4.6 juvenile from initial level. In marigold and crotalaria the rate of decrease in nematode population was fast. In marigold final population was reached to 2.3 juvenile from the initial level of 30.0 juvenile followed by crotalaria (check the spelling and make uniform) (3.0 juvenile). In rapeseed plant no significant difference in population before and after treatment was observed. Rapeseed plants almost acted as the bare field and populations in two counts were 24.3 and 20 juveniles per 20 g soil.

In tomato plant (CL 1104) the juvenile population within 76 days was increased by $122 \%$ than initial(30 juvenile/20g soil). In marigold and crotalaria population levels were reduced by $90 \%$ and $92 \%$ respectively. Oat reduced population level by $83 \%$ as compared to initial population. In rapeseed plant which almost acted as fallow land; population level was reduced by $33.3 \%$ than initial.

If fallowing is done in the field, long term fallowing is needed to reduce the nematode population provided that there is no susceptible host. From these observations it is clear that growing antagonist plant in infested soil significantly reduces population level of southern root knot nematode within specific time period.

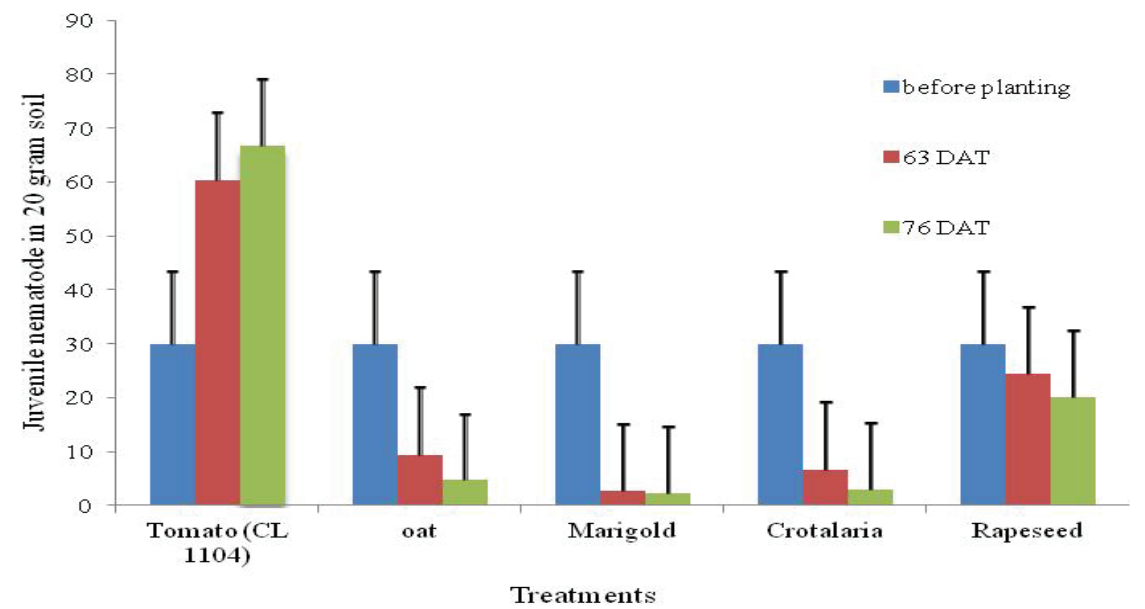

Figure 1. Comparison of juvenile nematode population before and after treatments

\section{CONCLUSIONS}

Better control of southern root knot nematode was achieved through the use of marigold followed by crotalaria and oat under the experiment in pot. These crops 
have multiple benefits. In some countries farmer sell marigold flowers and also earn the money. Oat is commonly used as green manuring crop in winter. Crotalaria is good green manuring crop that fix nitrogen and add organic matter in soil. Field evaluation should be done for further confirmation of effectiveness under field condition in different climatic conditions. From this experiment marigold followed by crotalaria and oat were identified as good substitute of chemical nematicides to suppress population of southern root knot nematode in soil.Selection of proper variety, planting density and durations under different climate and soil are important factors to use such plants.

Off-season tomato cultivation using plastic house is major income generating activities for the small scale farmers of Nepal. Due to continuous cropping of tomato, problem of southern root knot nematode (Meloidogyne incognita) is epidemic in the districts like Kaski,Palpa, Parbat,Syangja and Kathmandu valley which is the major cause of reducing productivity of off-season tomato. Without using costly, environment polluting nematicides, root knot nematode is manageable through yearly rotation of tomato with marigold or crotalaria at minimal cost. So through the adoption of this practice small scale as well as commercial farmers can manage southern root knot nematode in the plastic house.

\section{ACKNOWLEDGEMENT}

I would like to thank government of Nepal, MoAD and Japan International Cooperation Agency (JICA) for providing opportunity to take part in "vegetable cultivation technology for small scale farmers" training. I would also like to express thanks to the technical advisors and instructors of JICA,Tsukuba for providing continuous support and guidance .

\section{REFERENCES}

Agrios, G.N.2005 a,b,c,.Plant pathology (5th edition).Elsevier academic press.

Bhardwaj,L.N and C.H.Hogger.1984.Root Knot Nematodes of Chitwan district of Nepal. http: //brokert10.fcla.edu/. Retrieved April 2, 2010.

Brigde,J. and J.L.Starr.2007.Plant nematodes of agricultural importance. Manson publishing Ltd.P:40.

Crow, William T., A.G.Elizabeth and R.R.Kabana.1995.Green manures, an environmentally friendly way to control nematodes. Highlight of agricultural research.Volume42:4,1995.

District Agriculture Development Office.2009a,b .Annual Book. Ministry of Agriculture and Cooperatives, Department of Agriuclture,DADO,Kaski, Nepal.

Gazaway,W.1998.Nematode suppressive crops.Alabama cooperative extension system.Alabama AGM and Auburn universities.http://www.aces.edu. Retrieved: September 28,2010.

LeBlanc,David C.2004.Statistics:Concept and Application for Science.Jones and Bartlett Publishers, Canada.

Osbourn, A.E.2003.Molecules of interest saponin in cereals.Phytochemistry,Volume-62:p1-4 
Santo,G.S.,Mojtahedi h.,Hang A.N. and Wilson J.H.1991.Control of Columbia root knot nematode using rape seed and sudan grass as green manure. Paper presented Washington state potato conference and trade fare ,1991. http:/www. pacificbiomass.org. Retrieved 12 May,2010.

Sharma, R.D. and D.D.G.Scolari.1984.Efficiency of green manure and crop rotation in the control of nematode under Savannah codition. Nematologia Brasileria vol 8.In Crotalaria as a cover crop for nematode management: a review. Wang,K.H.,B.S.Sipes and D.P.Schmitt(Authors).2002.http://brokert10.fcla.edu.Retrieved October 13,2010.

Suatmadji, R. W. 1969. Studies on the effect of Tagetes species on plant parasitic nematodes. Stichting Frond Landbouw Export Bureau publicatie 47. H. Veenman Und Zonen N. V., Wageningen, Netherlands. p: 132.

Valenzuela,H. and J.Smith.2002.Common oats.Cooperative extension service, college of tropical agriculture and human resources, university of hawai.http: //www.ctahr.hawaii.edu. Retrieved:October 20,2010.

Vegetable Development Directorate.2011.Annual Book. Ministry of Agriculture Development, Department of Agriculture, VDD, Khumaltar,Lalitpur,Nepal

Wang,K.H.,B.S.Sipes and D.P.Schmitt.2002a,b.c.Crotalaria as a cover crop for nematode management:a review.http://brokert10. fcla.edu. Retrieved August 2,2010.

Wang,K.H.,C.R.Hooks and A. Ploeg.2007.Prtoecting crop from nematode pests :using marigold as an alternative to chemical nematicide. http://www.ctahr.hawaii.edu. Retrieved: October 13,2010. 